\title{
A NEW CASES EXISTENCE OF LEGAL FICTION PRINCIPLES INDONESIA LAW
}

\author{
Muldri Pudamo James Pasaribu', Henry Aspan², Solly Aryza ${ }^{3}$ \\ ${ }^{1}$ Faculty of Law, Universitas Simalungun, North Sumatera Indonesia \\ ${ }^{2,3}$ Universitas Pembangunan Panca Budi, Medan, North Sumatera, Indonesia \\ Email: sollyaryzalubis@gmail.com
}

\begin{abstract}
The principle of Fixie Rechts or Legal Fiction still embraced in Indonesian legislation. It does not matter that the policy is inconsistent with reality on the ground, which in fact creates more and more new problems. For example the application of laws in very remote areas. How can a rural person who has no access to information, if he does not comply with a rule that has been passed by the state through the state gazette, then without considering the absorption aspect of his information, he remains entangled in the law. Because he after the law was enacted, he was supposed to know the law. This study uses normative legal research method by reviewing the literature related to legal fiction. Surely the principle that is deemed irrelevant to its real condition like this deserves no longer applied. For that required seriousness of government and society in participating eliminate this law fiction principle. The results of this research show that Indonesia still enacts law government and culture as well, law maker or legislator and organization publish that.
\end{abstract}

Keywords: Critical Studies, Legal Fiction,Irrelevant Participation of Society.

\section{INTRODUCTION:}

Indonesian law recognizes Recht Fictie (legal fiction) as the assumption that something exists but, in reality, does not exist. Recht Fictie is also recognized in the field of law as the principle of legal fiction principle which states that everyone is considered to know the Law. Only to such an extent is accompanied by such an example without development. Though recht fictie includes an interesting topic of discussion, which needs to be further explored history, the origin of its application and further development..

The lack of papers on recht fictie can be understood as the lack of attention of jurists, including law professors, to the enforcement of this recht fictie. This is understandable because the recht fictie is explained in front of the students only at first glance with a very minimal example. [1]

Research on the reduction of the use of rechts fictie has been done but limited only in the field of law science alone. The result of his research, Legal Fiction Theory sees the understanding of society as the object of the rule. The socialization of legislation by the government is merely a procedural formality for a regulatory process regardless of the evaluation aspect. [2]

The scientific value of a discussion and problem solving on the legal issue under study depends on how the approach (approach) is used. If the approach is not correct, then the research weight is not accurate and the truth can be aborted. It is certainly not desired by any researcher. Similarly, in a normative study, using a different approach, the conclusions will be different. Therefore, it is important to know and understand some approaches required in a normative legal research.

The approach used in writing this paper is a philosophical approach. With a thorough, fundamental, and speculative philosophical nature, philosophical exploration will explore the legal issues in radical research normatively and explore them in depth. Socrater once said that the task of philosophy is not to answer the question, but to question the answer given. Thus, exploration in philosophy includes ontological doctrine, axiology (the doctrine of value), the espistemology (the doctrine of knowledge), the teleological (the doctrine of purpose) to clarify in depth, to the extent possible by the attainment of human knowledge.

Our research includes the normative legal research on Indonesian laws and regulations. To support applied research, basic research on the development of rechts fictie theory is important. The research we have done and will do is to develop rechts fictie (legal fiction) in Indonesian law. It is hoped that conclusions about the limitation of the theory of rechts fictie, the principle of rechts fictie and their examples will be made in various fields of law in Indonesia. Based on literature tracking, there is still very little discussion of the theories, principles and examples of rechts fictie. So it is deemed necessary to conduct research in order to know and understand the weaknesses of theory, principles and its application in positive law. 


\section{LITERATURE REVIEW:}

The position of theory in the science of law has a critical position in the process of creating the law itself. [3] The development of legal theory, has its place in the development of law as a whole. This development can not be separated from seeking the true meaning of justice that until now has never been discussed and disputed The existing legal theories and their numbers have reached hundreds, and even thousands can be considered to be a benchmark or a runway for the formation of an ideal legal system for society at a time [3]

The existence of legal principles that constitute a concrete manifestation of the existence of legal theory becomes the operational definition of the implementation of legal theory. The principles of law into legal theory can be more acceptable existence by ordinary people through its presentation with simple language. So hopefully, the existence of theory in law is not only a pile of the theory of non-functioning but acceptable and perceived usefulness by society. The principle of law is not the rule of law, because the principle of law is too general so that it can not speak too much. Implementation of the principle of law directly through subsumption or grouping, as a rule, is not possible, because it first needs to be formed more concrete content [4].

That is, with the enactment of legislation in the official sheet as referred to in this provision, everyone is deemed to have known it. The theory of legal fiction assumes that once a legal norm is enforced, then at the same time everyone is considered to know the law. One's ignorance of the law cannot relieve a person of a lawsuit. In Latin Igronantia iuris neminem excusat. Views and thoughts based on the legal fiction theory commonly adopted by the state with the civil law system. Thus according to H.A.S Natabaya, quoted Agus Surono, 2013. Ignorance of a person against a law or a law is not a forgiving excuse. This is contrary to the sense of justice that exists in society. How can someone who does not know a rule be punished for violating an unknown rule? Is not the rule a reflection of people's lives that require regulation?

Discussing the concept of adulthood and immature according to Western civil law, Djojodigoeno, Professor of Customary Law, states that over 21 years of age to determine adulthood or immature is a fiction. Fiction can be interpreted as unclear and not assertive or inconsistent. This is not by the customary law that is based on reality [5].

The explanation of rechts fictie is also present when understanding the subject of law. The validity of a person as the right bearer, from the moment he is born and ends when he dies. In fact, for his sake, it can be calculated retroactively until the person starts in the womb, provided he is born alive. It is important that the inheritance be open at a time, where the person is still in the womb [5].

Law Number 35 Year 2014 on Amendment to Law Number 23 Year 2002 regarding Child Protection, Article 1 point 1 reads: "A child is a person not yet 18 years of age, including a child still in the womb." The provisions of this Act contain the principle of rechts fictie in it. The child who is in the womb even though he has not been born into the world has been likened to a child who was born, even 18 years old [6]. Regarding the rechts fictie in the subject of law, this is firmly stipulated in Article 2 of the Civil Code which reads as follows: "The child in the womb of a woman is considered to exist as having been born when also the interests of the child shall desire it."

\section{RESULT AND DISCUSSION:}

\subsection{Principles and Legal Fiction Theory}

Van Apeldoorn gives the opinion, fictie or fiction is that we accept something that is not true as something that is true or in other words we accept what really does not exist as exist or that actually exists as nothing. In this sense human need protection of interest, which is filled by various social rules one of which is the rule of law. Because the rule of law protects human interests, it must be obeyed by other human beings. Thus arising awareness to comply with the rule of law, to protect its interests.

This research uses doctrinal research method that is to study the theories, legal principles related to the existence of rechts fictie in the positive law of Indonesia. Under Indonesian law, the principle of legal fiction assumes that the enactment of legislation has a binding force, binding on everyone to recognize the existence of the rule. The enactment of regulations does not depend on the equitable access to information received by the public. Whether the public receives information about the legislation or not, does not matter to the inviting party, in this case, is the government through its legislative body. Here lies the lack of this legal fiction principle. The government has the opportunity to be arbitrary. Especially in a society that is considered to act unlawfully or rule out the law even though for reasons not yet know the existence of legislation.

Legal fictions can be understood from lawmakers' desire for a short formulation. Sometimes legislators use the principle of legal fiction while at the same time actually minimizing or even not using it at all in the formation of rules. Logically, if a principle, whether express or implied in legislation is considered to create difficulties for society, then the cause of such adversity should be avoided from the beginning. This is to achieve the purpose of the law itself. Legal certainty, legal justice and legal benefit in society.

According to Agus Surono in his dissertation research, the use of legal fiction in the legislation and the law teaches cause great loss. The use of such legal fictions resulted in the habit of the lawyers using fiction inappropriately. Because in the Law and the literature of legal science, jurists often use fiction. Finally, jurists because they are used to the use of legal fiction, become very fluent in using it. That is why legal fiction also plays a role in the courts and 
sometimes plays a very dangerous role. For judges, fiction is a fascinating tool, because fiction gives the judge the ability to achieve the desired state.

\subsection{Reduction in the Use of Legal Fiction in the Field of Legal Laws}

The state must fully protect community participation in every stage of legislative establishment in its implementation. The authorities do not violate the principles of democracy. So the provision of public space or public participation is an absolute demand in a democratic country like Indonesia. Every formation of legislation must involve the community. Whether through an audience or community organizations. Unfortunately, these involvement processes are often not implemented. So that suddenly emerged just the new laws and regulations. Regarding the role and participation of the community is reflected in one of the principles of the establishment of legislation regulated in Article 5 Sub-Article g of Law Number 12 Year 2011 which is the principle of transparency.

Whereas in the process of formulating legislation, the community must be directly involved in all stages of legislative establishment. It started from the stage of planning, drafting, discussion, endorsement and determination and enactment. These stages are carried out according to the needs and conditions. The provision of Article 96 Paragraph (4) of Law Number 12 Year 2011 concerning the Establishment of Laws and Regulations states that "to facilitate the community in providing oral and written input, every draft legislation should be easily accessible by the public. "The reality to get draft legislation is complicated, especially at the regional level.

The importance of community participation in the regulatory process is due to:

1. To obtain a good regulatory process, qualify and based on community-based expertise or experience.

2. For the rules to be passed to be truly a reflection of the living reality of society. Both regarding political, economic, social, other fields.

3. Grow the sense of belonging (sense of belonging), sense of responsibility (sense of responsibility), and accountability of the legislation (sense of accountability).

So far, the involvement of community participation in the formulation of the law is merely a formality.

The forums that can accommodate the rights of the community are:

1. RDP

2. Working visit (kunker)

3. Socialization

4. Seminars, workshops and/or discussions

Of course, not all people are invited to express their opinions in the forums. Only those who are interested in the draft legislation. If you want to form a Health Act then invited are doctors, nurses, and other health workers. Likewise, when establishing the Manpower Act will certainly invite representatives of trade unions and employers. Because here they are interested parties. Society must be proactive in voting if the substance of the bill is concerned with selfinterest, class, and general. The more relevant aspirations enter, the greater the likelihood of enacting the principle of legal fiction. Because with the equitable information in the community, minimize the imposition of the principle of legal fiction.

\subsection{Legal Fiction In The Field Of Private Law}

In the field of civil law, legal fiction lies in the subject of recognition as the subject of law. Recognition of the human being as the subject of law since still in the womb of his mother with the provisions of life born. This provision is of (relevant) importance if the child's interests are to be desired, for example, in the case of obtaining inheritance or grant. Law recognizes the status of a legal subject. The admission states that no punishment could result in the loss of civil rights as a legal subject (Article 3 of the Criminal Code). It means no matter how wrong a person is that he or she is sentenced by a court, such punishment should not deprive a person of legal standing as a legal subject.

The Republic of Indonesia as a state law acknowledges human beings as legal subjects supporting rights and obligations. All citizens have equal status in law and government and are obliged to uphold the law and government with no exceptions (Article 27 paragraph (1) of the 1945 Constitution). In other countries, as has been experienced by a South African country ruled by a white regime, its rulers adhere to a race of discrimination, not all human beings are recognized as law sub-articles. A black man is not recognized as the subject of the law of supporting rights, but only as a supporter of obligations.

So the fetus who is still in the womb of his mother, although not yet born into the world, and not yet know whether to be born alive or not, if his legal interests desire, then he is regarded as a legal subject. Same as his old brother. For example when the opening of the inheritance because his father died. So the child does not lose his right to inheritance, even though he is not yet born. In contrast to the enactment of the principle of legal fiction in the field of statutory law, which is perceived as incompatible with a sense of justice, in civil law, precisely in the presence of legal fictions, children who are still fetus protected their legal interests.

Also, other legal fictional principles in civil law, found in adult and immature concepts (meerderjarig and minderjarig) In response to the concept of mature and immature according to Western civil law. Djojodigoeno, 
professor of Customary Law, stated that: "The age limit of 21 years for determining adulthood or not yet dehuman is a fiction Fiction can be interpreted as unclear and not assertive or inconsistent It is not by the customary law based on reality. Unlike the concept of immature and adulthood according to customary law, Djojodigoeno declare law adat does not know the age limit to determine whether it is immature or adult.

In customary law is not known fiction as in Western civil law. The customary law determines incidentally whether a person is related to age and the development of his soul should be considered capable or incompetent, capable or unable to perform certain legal acts in a particular relationship. That is, whether he can calculate and maintain his interests in the deeds he faces. Furthermore, he states that the boundary between the immature and the immature can only be seen from the incompetent and capable of performing legal acts. Not being able to mean is not able to calculate and maintain its interests.

If we consider Djojodigoeno's opinion above, the fiction is interpreted as unclear, unambiguous or inconsistent. It could be someone has reached the age of 21 years, but in fact, he is not capable of doing a legal act while on the other hand, there are people who are aged 17 years but have been able and able to be responsible for performing an act, especially a legal act. It is called legal fiction in the concept of adulthood and immature, in the realm of civil law.

According to the Legal Fiction theory pioneered by Von Savigny, the legal entity is considered a private body that is fictitious, separate from the personal person who is the administrator. Therefore, the legal act undertaken by its management can not be regarded as the act of a legal entity, but the deed of the person other that is accountable to the legal entity.

On this basis, the body of the law does not act directly, but through the actions of others, namely the caretaker. The Board is a person acting on behalf of a legal entity. Thus, the actions of the board are accountable to legal entities. All actions done by the board, the body of law is responsible. In other words, the board acts for and on behalf of a fictitious legal entity.

Based on the theory of fiction the legal entities that conduct unlawful acts can be sued not based on Pasai 1365 KUHPdt, but based on Article 1367 KUHPdt. If you follow this fictional theory, people are faced with a situation that is contrary to reality. The fact that anyone who commits a legal act can be sued through Article 1365 of the Criminal Code.

\subsection{Legal Fiction In Indonesian Law}

The Great Dictionary of Bahasa Indonesia contains a lot of life field labels and a field of science that shows the use of the word in question. Among these disciplines are state administration, religion, economics, finance, law, politics and government, literature, sociology, engineering, telecommunications, and others. It shows that in certain fields of science there are commonly used words.

Although both use the Indonesian language, but the things mentioned in the Indonesian language are general. Indonesian in everyday sense can be different from Indonesian in the sense of law. The language of law may be represented by a variety of individual languages, in addition to other languages. Characteristic is characterized by the use of measurable words and strives to formulate the definitions that it wishes to convey exactly. Hence the impression arises that the variety of legal language in this regulatory language or Act is drab and dry.

The legal language requires a single notion of a word or words in order not to give rise to other meanings.

The objectives are, among others, not to generate mutualtafsir, in order to provide certainty of understanding which in turn provides legal certainty. The jurists can not work with common and vague language terms. Even Fuller requires that the law be formulated in a language that people can understand. The notions of law that exist are lifted from the everyday sense, some are created specifically as a technical sense. Sale and purchase, ill-treatment, compensation, and such are legal notions raised from day-to-day understandings.

Another case with the notions, such as, indictment, interlocutory, joint responsibility, and so forth. Some even come from a foreign language, then because it is commonly used daily in the field of law, and then turned into a legal language. It is important to understand that even if a sense is derived from everyday language, but once it is made into a legal sense, then the meaning that can be given to him is only what the law gives him.

Although the language of the law requires clear words, light, and no other interpretation, it is not always easy to construct a legal sense that really gives certainty to the wearer. In the case of legal notions having a relatively low degree of certainty, in order to be certain, it is left to the interpretive practice especially by the courts.

In support of legal certainty, legal language has several functions as follows: 1). As a rule, the law is made one of them to regulate the life of nation and state. Legal rules contained in the form of Laws, Keppres, kepmen, and others. 2). Giver of uniqueness, the language of law is different from other scientific languages. The law has a characteristic in terms of the composition of the rules, namely detailed, chronological, causal relationships, and attempts to explain a problem in a long sentence discourse, as well as its particular language style and special meaning. 3). The bearer of legal authority, the language of the law contains orders and prohibitions. 4). Terms of reference for professionals and legal theorists, when practicing law the rule of law in the form of a law made reference in solving legal problems. 5). 
The enrichment of Indonesian vocabulary, legal terms adopted from Dutch, English, Arabic, and local languages, so that the terms can enrich the vocabulary in Indonesian.

The use of legal terminology primarily derived from foreign terms is often inappropriate regarding its meaning and impact when the term is used in the practice of law in society. In the Great Dictionary of Indonesian fiction is a fiction, a delusion, not based on reality. According to Lilis Hartini, this means, the term law is formed by way of engineered and certainly not by the theory of truth and legal certainty.

While according to the legal dictionary, fiction or in the original language, fictio is a wish, a legal form, a construction law, a law building, in addition to the legislation of the law. Judging from the theory of justice the use of legal fiction potentially lead to injustice. Because the person who does not know his or her rules is punished the same as the one, who knows. If viewed from the aspect of legal certainty, this legal fiction is needed so that there is no chance of someone dodging from the law.

With black fiction can be white, and vice versa. It is dangerous in the process of discovering truth and justice, for example by presuppositions. Conjectures must be separated from fiction. Fiction is the unrighteousness of creation alone; a presumption may be true, probably not. The important role held by this presumption will be further reviewed. The truth of the use of legal fiction should be in doubt when viewed from the existing theories of truth. Logically it is also scientifically unjustifiable. Because the reality is quite the opposite, even though the legal regulation is outlined in the State Gazette. Law enforcement officers may also not understand the rules of law.

There is synchronization when entering foreign elements into the treasury of legal terms in Indonesia. The terms are arguably consistent with the procedure of forming foreign terms into Indonesian. Term is quite familiar to the community, which is simpler, and less confusing, such as, abolition becomes abolition, amnesty becomes amnesty, arbitration becomes arbitrage. Case becomes case, civil becomes civil, client becomes client, dictum becomes dictum, exception becomes exception, fact become facts, fictie becomes fiction, legislation becomes legislation, legitimacy becomes legitimacy, and public becomes public.

It is important to understand the relationship between language and law because there is a synergistic relationship between the two. Language and law is an explanation of human life in society. In society, the law is one means of creating order and social order, formulated through language. The law also will not be separated from the culture of the legal community itself. One of society's culture can be reflected in its language. Indonesian experts criticize the use of language that violates PUEBI. Languages in legal prosecutors such as statutory regulations, notarial deeds, court documents of various letters, often disobey the principle. In particular, the use of legal fiction regarding the law as discussed above is seen to obscure meaning in the process of seeking truth itself and not by the theory of truth and justice.

\section{CONCLUSION:}

A critical review of the principle of legal fiction in Indonesian law is an effort to find a solution to achieve legitimate objectives, certainty, justice and legal benefit for the community. Concrete efforts that can be implemented are strengthening the dissemination of information from the government and increasing involvement of community participation in attending forums aimed at accommodating community aspirations related to draft laws and regulations. In the field of civil law, the use of legal fiction can still be continued if the interests of law require and remain based on the principle of justice for the subject of law. Judging from the Indonesian legal language should no longer use the principle of legal fiction. It is in line with the use of the principle of legal fiction in the legislation, for the sake of law enforcement that is and uphold the truth.

\section{REFERENCES:}

1. S. Aryza, M. Irwanto, Z. Lubis, A. Putera, and U. Siahaan, "A Novelty Stability Of Electrical System Single Machine Based Runge Kutta Orde 4 Method," IOSR J. Electr. Electron. Eng. Ver. II, vol. 12, no. 4, pp. 2278$1676,2017$.

2. A. H. Lubis, "ICT Usage Amongst Lecturers and Its Impact Towards Learning Process Quality," vol. 34, no. 1, pp. 284-299, 2018.

3. M. Parasol, "The impact of China's 2016 Cyber Security Law on foreign technology firms, and on China's big data and Smart City dreams," Comput. Law Secur. Rev., vol. 34, no. 1, pp. 175-179, 2018.

4. H. Aspan, I. M. Sipayung, A. P. Muharrami, and H. M. Ritonga, "The Effect of Halal Label, Halal Awarness, Product Price, and Brand Image to the Purchasing Decision on Cosmetic Products (Case Study on Consumers of Sari Ayu Martha Tilaar in Binjai City)," Int. J. Glob. Sustain., vol. 1, no. 1, p. 55, 2017.

5. R. Sitompul, U. Of, I. Sumatera, M. North, and S. Indonesia, "IMPLEMENTATION ANALYSIS AGAINST CHILDREN IN MARRIAGE," no. 2, 2014.

6. S. K. Goyal and D. K. Palwalia, "Analysis of performance parameters and estimation of optimum capacitance for asynchronous generator," Eng. Sci. Technol. an Int. J., vol. 19, no. 4, pp. 1753-1762, 2016. 